|| French Fim Directoors ||||
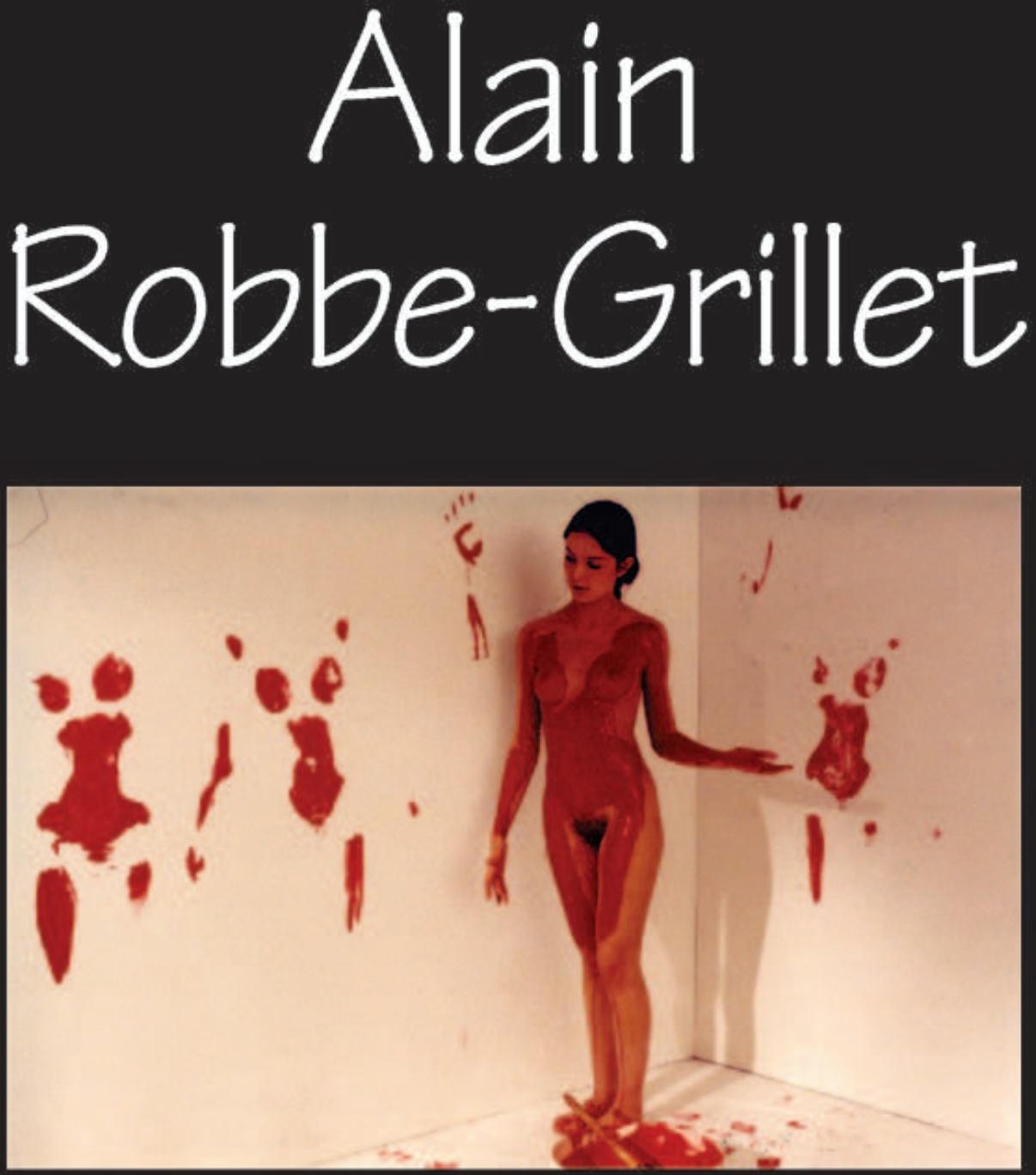

JOHN PHILLIPS 


\section{Alain Robbe-Grillet}

\section{MANCHESTER \\ 1824}

Manchester University Press 
FRENCH FILM DIRECTORS

DIANA HOLMES and ROBERT INGRAM series editors DUDLEY ANDREW series consultant

Chantal Akerman MARION SCHMID

Auterism from Assayas to Ozon: five directors KATE INCE Jean-Jacques Beineix PHIL POWRIE

Luc Besson SUSAN HAYWARD

Bertrand Blier SUE HARRIS

Catherine Breillat DOUGLAS KEESEY

Robert Bresson KEITH READER

Leos Carax GARIN DOWD AND FERGUS DALEY

Claude Chabrol GUY AUSTIN

Henri-Georges Clouzot CHRISTOPHER LLOYD

Jean Cocteau JAMES WILLIAMS

Claire Denis MARTINE BEUGNET

Marguerite Duras RENATE GÜNTHER

Georges Franju KATE INCE

Jean-Luc Godard DOUGLAS MORREY

Mathieu Kassovitz WILL HIGBEE

Diane Kurys CARRIE TARR

Patrice Leconte LISA DOWNING

Louis Malle HUGO FREY

Georges Méliès ELIZABETH EZRA

François Ozon ANDREW ASIBONG

Maurice Pialat MARJA WAREHIME

Jean Renoir MARTIN O'SHAUGHNESSY

Alain Resnais EMMA WILSON

Jacques Rivette DOUGLAS MORREY AND ALISON SMITH

Eric Rohmer DEREK SCHILLING

Coline Serreau BRIGITTE ROLLET

André Téchiné BILL MARSHALL

François Truffaut DIANA HOLMES AND ROBERT INGRAM

Agnès Varda ALISON SMITH

Jean Vigo MICHAEL TEMPLE 
French Film Directors

\title{
Alain Robbe-Grillet
}

\author{
JOHN PHILLIPS
}

Manchester University Press

MANCHESTER 
Copyright (C) John Phillips 2011

The right of John Phillips to be identified as the author of this work has been asserted by him in accordance with the Copyright, Designs and Patents Act 1988.

Published by Manchester University Press

Altrincham Street, Manchester M1 7JA, UK

www.manchesteruniversitypress.co.uk

British Library Cataloguing-in-Publication Data

A catalogue record for this book is available from the British Library

Library of Congress Cataloging-in-Publication Data applied for

ISBN 978 ○ 719077371 hardback

First published 2011

The publisher has no responsibility for the persistence or accuracy of URLS for any external or third-party internet websites referred to in this book, and does not guarantee that any content on such websites is, or will remain, accurate or appropriate.

Typeset in Scala with Meta display

by Koinonia, Manchester 